\title{
STATUS, MASALAH, DAN ALTERNATIF PEMECAHAN MASALAH PADA PENGEMBANGAN BUDIDAYA UDANG VANAMEI (Litopenaeus vannamei) DI SULAWESI SELATAN
}

\author{
Utojo*) dan Abdul Malik Tangko*) \\ *) Balai Riset Perikanan Budidaya Air Payau, Maros
}

\section{ABSTRAK}

Udang vanamei merupakan udang introduksi seiring menurunnya produksi udang windu di tambak karena penyakit WSSV. Prospek pengembangan budidaya udang vanamei di Sulawesi Selatan sangat baik karena luas wilayah pertambakannya mencapai 90.540 ha yang pernah digunakan untuk kegiatan budidaya udang windu dengan mengaplikasikan mulai dari teknik budidaya tradisional hingga intensif. Budidaya udang vanamei belum meluas di masyarakat, diharapkan dalam pengembangannya dapat meningkatkan kembali produksi udang di Sulawesi Selatan. Udang vanamei memiliki kelebihan dibandingkan komoditas alternatif lainnya dan masih memiliki peluang pasar ekspor serta total biaya produksi juga lebih kecil. Salah satu faktor yang menyebabkan pembudidaya tambak di Sulawesi Selatan susah menerima udang vanamei adalah mereka pada umumnya bermodal kecil dan berpandangan bahwa budidaya udang vanamei hanya sesuai dan akan menguntungkan bila dibudidayakan secara semi intensif dan intensif, yang dalam operasionalnya memerlukan investasi cukup besar terutama biaya pakan dan harga bibit yang cukup mahal. Di samping itu, udang vanamei juga sudah terkena penyakit virus white spot seperti yang terjadi pada udang windu. Pemecahannya seperti penyuluhan ke pembudidaya, kalau udang vanamei dapat juga dilakukan secara tradisional dan tradisional plus dengan keuntungan cukup memuaskan berkisar Rp 7.603.000,- -- Rp 22.264.000,-/ha/siklus; pengadaan breeding center udang vanamei; diagnosa penyakit TSV, WSSV, dan IHHNV secara dini mulai dari calon induk di panti benih, benur hingga masa pembesaran di tambak; diseminasi teknologi budidaya udang vanamei bebas penyakit di tambak perconto han dempond; pembentukan koperasi usaha yang saling menguntungkan antar seluruh komponen; dan memberi pengertian dan pembinaan ke pembudidaya untuk tetap mempertahankan budidaya bandeng dengan mengembangkan usaha budidaya udang vanamei.

KATAKUNCl: status, permasalahan dan pemecahannya, budidaya udang vanamei, Sulawesi Selatan

\section{PENDAHULUAN}

Udang vanamei (Litopenaeus vannamei) atau dikenal dengan Pacific White Shrimp merupakan udang introduksi yang secara ekonomis bernilai tinggi karena diminati oleh pasar Amerika dan dunia. Udang vanamei masuk ke Indonesia pada tahun 2001 dan mulai dibudidayakan di tambak daerah Banyuwangi dan Situbondo, Jawa Timur, seiring dengan menurunnya produksi udang windu akibat terserang penyakit virus white spot atau White Spot Syndrome Virus (WSSV) sehingga pertumbuhannya juga sangat lambat (Sugama, 2002).

Dalam pengembangannya telah dilakukan rintisan usaha kegiatan budidaya udang vanamei oleh beberapa pembudidaya dengan teknik budidaya mulai dari sederhana hingga intensif. Udang vanamei memiliki pertumbuhan yang cepat, relatif tahan terhadap serangan penyakit, dan memiliki toleransi yang tinggi terhadap perubahan kondisi lingkungan (Widodo \& Dian, 2005). Di samping itu, Briggs et al. (2004) juga menyatakan bahwa udang vanamei tumbuhnya lebih cepat dibandingkan dengan udang windu dan udang stylirostris (3 g/minggu), dapat ditebar dengan kepadatan tinggi hingga lebih dari 150 ekor $/ \mathrm{m}^{2}$, tahan pada kisaran salinitas yang lebar (0,5-45 ppt), kebutuhan protein pakannya lebih rendah (20\%-35\%, serta mampu mengonversi pakan dengan lebih baik (FCR 1,2--1,6).

Kegiatan usaha budidaya udang vanamei di tambak merupakan satu di antara pemanfaatan kawasan pesisir yang diharapkan mampu memberikan kontribusi yang cukup besar terhadap pendapatan pemerintah daerah Provinsi Sulawesi Selatan, penyedia lapangan kerja bagi masyarakat pesisir dan perolehan devisa negara yang cukup potensial. Luas tambak di Sulawesi Selatan pada tahun 2001 telah mencapai 86.888 ha dan pada tahun 2005 meningkat menjadi 90.540 ha (Anonim, 2001; 2005). Dengan potensi tambak yang ada dan untuk meningkatkan produksi udang secara berkelanjutan di daerah tersebut saat ini, diharapkan dapat diperoleh dari pengembangan budidaya udang vanamei (Litopenaeus vannamei) sebagai komoditas alternatif selain udang windu. 


\section{STATUS DAN PERMASALAHAN UDANG VANAMEI}

\section{Wilayah dan Habitat Penyebarannya}

Habitat asli udang vanamei adalah dasar perairan yang cenderung berlumpur pada daerah pantai dengan kedalaman mencapai $72 \mathrm{~m}$. Penyebarannya meliputi wilayah perairan Pasifik Barat, Teluk Meksiko, Panama, Peru, dan Ekuador. Udang vanamei memijah pada perairan bersalinitas tinggi, larvanya yang bersifat planktonik, terbawa arus ke wilayah perairan estuaria atau teluk yang terlindung dengan subtrat lumpur. Menurut Benzie (2000), perairan Lagoon Mar Muerto Teluk Tehuantepec yang merupakan salah satu daerah estuari terluas di Meksiko, merupakan tempat udang vanamei mencari makan. Pada puncak musim penangkapan (Juni dan Agustus) produksi hasil tangkapan udang vanamei dapat mencapai 10 ton (Garcia \& Le Reste, 1981). Udang tersebut tertangkap di daerah lago on yang bersubtrat lumpur pada kedalaman lebih dari atau kurang dari $1 \mathrm{~m}$.

Wilayah yang juga terkenal sebagai tempat penyebaran udang vanamei adalah Teluk Fonceca di perairan Honduras. Pada kawasan perairan tersebut terdapat 33 daerah ekosistem estuari yang tersebar pada beberapa tempat seperti Estero Bernado, Bahia San Lorenzo, Chismuyo, dan Chapulin (Travis, 2002).

\section{Pakan}

Selain sifat biologi yang telah diteliti di dalam pengembangan budidaya udang vanamei juga mengenai pakan buatan karena keberhasilan usaha budidaya udang dengan sistem semi intensif dan intensif sangat ditentukan oleh pakan yang cukup memadai dan berkualitas. Salah satu unsur yang sangat menentukan kualitas pakan buatan adalah kandungan proteinnya di samping unsur-unsur lainnya (Gambar 1). Di dalam budidaya udang, baik untuk vanamei maupun jenis udang

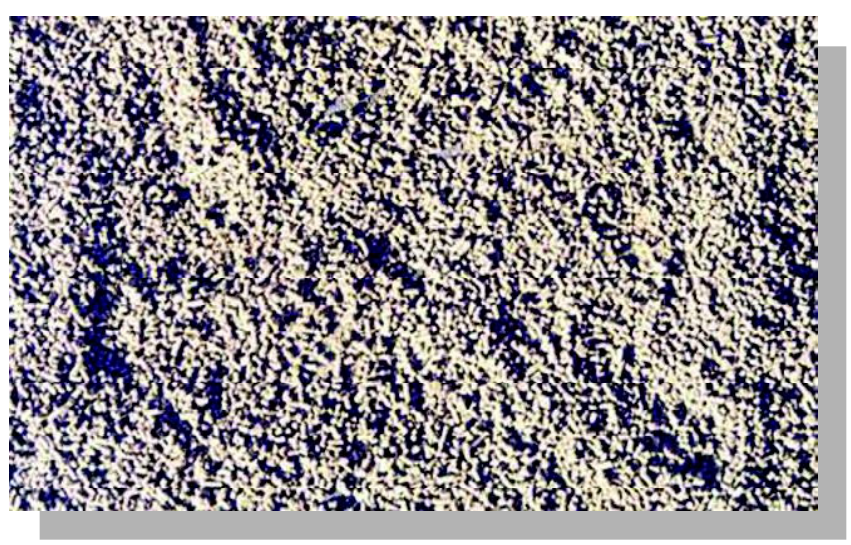

Gambar 1. Pakan buatan (pelet) untuk budidaya udang vanamei lainnya, biaya pakan yang terserap sekitar 60\%-70\%dari biaya operasional dalam satu siklus budidaya. Kureshy \& David (2000) telah melakukan percobaan mengenai pengaruh kandungan protein dalam pakan terhadap pertumbuhan yuwana udang vanamei di laboratorium dengan perlakuan yaitu 16\% 32\% dan 48\% Berdasarkan hasil analisis statistika ternyata ada perbedaan yang signifikan di antara ketiga perlakuan tersebut. Kandungan protein yang terbaik untuk pertumbuhan yuwana udang vanamei yang dicobakan adalah pakan dengan kandungan protein $32 \%$ Sedangkan perlakuan kandungan asam lemak $10 \% 25 \%$ 0,5\% dalam pakan yang diberikan pada yuwana udang vanamei selama pemeliharaan 6 minggu tidak berpengaruh nyata terhadap pertumbuhannya.

Selain unsur-unsur tersebut di atas, salah satu unsur yang sangat penting untuk diketahui di dalam pakan udang vanamei yaitu unsur nitrit, oleh karena kandungan unsur yang melampaui kebutuhan optimal kehidupan dan pertumbuhan udang vanamei dapat menyebabkan keracunan atau kematian pada udang. Menurut Lin \& Chen (2001), bahwa tingkat toksit nitrit terhadap udang vanamei tergantung pada tingkat salinitas media pemeliharaan. Hasil penelitian mengenai daya toksit nitrit terhadap yuwana udang vanamei pada tingkat salinitas yang berbeda (15, 25, dan 35 ppt). Dari hasil penelitian tersebut menunjukkan bahwa daya toksit LC 50 amonia-N pada salinitas 15 ppt adalah 69\%-90\%lebih rendah dibandingkan dengan LC 50 amonia-N pada salinitas 25 ppt yaitu 90\%-97\% selanjutnya LC 50 amonia-N pada salinitas 25 ppt lebih rendah dibandingkan LC 50 amonia-N pada 35 ppt setelah 12--96 jam. Selanjutnya Sprague (1971) kandungan nitrit pada salinitas 15,25 , dan 35 ppt yaitu 6,$1 ; 15,2 ;$ dan $25,7 \mathrm{mg} / \mathrm{L}$ pada $\mathrm{pH}$ 8,02 dan temperatur air $18^{\circ} \mathrm{C}$, adalah LC 50 amonia-N 15 ppt (76\% lebih rendah dari pada salinitas 35 ppt, dan LC 50 amonia-N pada level 25 ppt (41\% lebih rendah daripada salinitas 35 ppt.

\section{Penyakit}

Jenis penyakit yang sering menyerang udang vanamei sebelum masuk ke Indonesia adalah White Spot Syndrome Virus (WSSV), Taura Syndrome Virus (TSV), dan Infectious Hydrodermal and Hematopoietic Necrosis Virus (IHHNV). Menurut beberapa hasil penelitian yang telah dilakukan, ternyata udang vanamei lebih peka terhadap penyakit TSV bila dibandingkan penyakit WSSV dan IHHNV. Ketiga jenis penyakit tersebut sampai saat ini memang masih menjadi permasalahan dalam budidaya udang termasuk udang vanamei. Di Ekuador produksi udang vanamei merosot tajam akibat serangan penyakit WSSV. Di Amerika Latin hanya dua negara yang dinyatakan bebas WSSV yaitu Brazil dan Venezuela. Taiwan sebagai negara pertama di 
Asia yang mengintroduksi dan membudidayakan udang vanamei pada tahun1994, pernah mengalami kebangkrutan akibat ribuan hektar tambak budidaya udang vanamei terserang penyakit WSSV. Di Ekuador sebagai negara pertama yang membudidayakan udang vanamei pernah mengalami kebangkrutan oleh penyakit TSV dan sampai saat ini belum bisa diatasi dengan tuntas. Sedangkan di Asia Tenggara serangan penyakit TSV terbesar pernah terjadi di Malaysia sehingga pemerintah setempat pernah melarang udang vanamei masuk ke negaranya. Di Indonesia sampai saat ini penyakit TSV sudah menyebar ke beberapa daerah melalui impor induk dan benih udang vanamei (Sihombing et al., 2005 dan Sugama, 2002).

\section{Status Udang Vanamei di Sulawesi Selatan}

Di Sulawesi Selatan walaupun budidaya udang vanamei belum meluas di masyarakat, namun udang vanamei sebagai komoditas alternatif secara bertahap akan menggeser posisi udang windu sebagai komoditas utama dalam meningkatkan kembali produksi udang di Sulawesi Selatan. Udang vanamei sebagai komoditas alternatif telah disebut memiliki beberapa kelebihan atau keunggulan dibandingkan komoditas alternatif lainnya, seperti udang windu serta masih memiliki peluang pasar ekspor, dan total biaya produksi juga lebih kecil.

Berdasarkan hal tersebut di atas, maka pemerintah dalam hal ini Dinas Kelautan dan Perikanan Sulawesi Selatan mengijinkan pengembangan budidaya udang vanamei, di samping tetap melakukan budidaya udang windu dan ikan bandeng. Hal ini mengacu pada Surat Keputusan Menteri Kelautan dan Perikanan No. KEP.41/ MEN/2001 yang meresmikan diijinkannya pengembangan budidaya udang vanamei di Indonesia, dengan tujuan untuk meningkatkan produksi udang nasional.

\section{TEKNIK BUDIDAYA, PRODUKSI, DAN PENGEM- BANGANNYA}

\section{Lokasi dan Standar Kualitas Air}

Persyaratan lokasi tambak untuk budidaya udang vanamei harus memenuhi persyaratan teknis dan nonteknis. Secara teknis adalah (1) Terletak di daerah pantai dengan fluktuasi air pasang dan surut antara 2--3 m; (2) Jenis tanah sebaiknya liat berpasir untuk menghindari kebocoran tambak; (3) Memiliki sumber air tawar dengan debit atau kapasitas cukup besar sehingga kebutuhan air tawar terpenuhi; (4) Lokasi tambak sebaiknya memiliki green belt yang berupa hutan mangrove di antara tambak dan pantai. Persyaratan non teknisnya adalah (1) Dekat dengan produsen benih; (2) Dekat sumber tenaga kerja; (3) Dekat dengan sentra perekonomian sehingga mudah mendapatkan berbagai bahan pokok untuk produksi; (4) Lokasi terjangkau oleh sarana transportasi kendaraan roda empat, saluran penerangan, dan alat komunikasi; (5) Ada akses untuk mendapatkan pembinaan dari Dinas Perikanan dan Kelautan setempat dan; (6) Aman dari pencurian (Haliman $\&$ Adijaya, 2005).

Peryaratan kualitas air tambak untuk budidaya udang vanamei antara lain salinitas 15--25 ppt; pH 7,5--8,5; suhu air $26^{\circ} \mathrm{C}--32^{\circ} \mathrm{C}$; alkalinitas total $120--150 \mathrm{mg} / \mathrm{L}$; bikarbonat $>80 \mathrm{mg} / \mathrm{L}$; kesadahan total $>2.500 \mathrm{mg} / \mathrm{L}$; $\mathrm{H}_{2} \mathrm{~S}<0,1 \mathrm{mg} / \mathrm{L} ; \mathrm{PO}_{4}$ 0,5--1 mg/L; transparansi 30--60 cm, plankton dominan alga hijau dan diatom, oksigen $>4$ $\mathrm{mg} / \mathrm{L}$, dan kedalaman air tambak minimal $1 \mathrm{~m}$. Tekstur tanah tambak liat berpasir dan tidak porus.

\section{Persiapan Tambak}

Persiapan tambak untuk budidaya udang vanamei secara intensif dilakukan berurutan sebagai berikut: (1) Penjemuran tanah dasar tambak hingga kering; (2) Pembersihan dan perbaikan peralatan seperti kincir, kabel, saringan, pipa paralon, dan lain-lain; (3) Pengolahan tanah dengan membuang lumpur $10 \mathrm{~cm}$ di bagian atas pelataran tambak dan pemberian desinfektan kaporit 20--30 mg/L; (4) Perbaikan bocoran pematang dan perataan tanah dasar tambak; (5) Pengecekan potensial redoks hingga \pm 50 $\mathrm{mV}$, penghitungan kebutuhan kapur tergantung dari kondisi tanah dasar tambak; (6) Pemasangan saringan pada pintu-pintu tambak; (7) Pengisian air setinggi $20 \mathrm{~cm}$ atau macak-macak di pelataran tambak; (8) Diberikan saponin 15--20 mg/L (150--200 kg/ha); (9) Dimasukkan air setinggi 100--120 cm pada tambak; (10) Diberikan fermentasi minimal satu kali pemberian dengan bahan fermentasi probiotik (super media 1) yang terdiri atas (katul $10 \mathrm{~kg}$, saponin $10 \mathrm{~kg}$, ragi tape $250 \mathrm{~g}$ )/ha, direndam dalam air tawar 24--36 jam tanpa aerasi; (13) Setelah air sesuai standar, kemudian benur ditebar.

Persiapan tambak budidaya udang vanamei secara tradisional hingga tradisional plus sebagai berikut: (1) Penjemuran tanah dasar tambak hingga kering; (2) Perbaikan bocoran pematang dan perataan tanah dasar tambak; (3) Pemasangan saringan pada pintu-pintu tambak; (4) Tambak diisi air setinggi $20 \mathrm{~cm}$ secara macak-macak; (5) Diberikan saponin 15--20 mg/L untuk membunuh ikan liar sebanyak 150--200 kg/ha; (6) Diberikan pupuk Urea dan TSP sebanyak $150 \mathrm{~kg}$ dan $75 \mathrm{~kg} / \mathrm{ha}$; (7) Diberikan pupuk susulan setelah udang berumur 1 bulan yaitu Urea dan TSP sebanyak $10 \%$ dari pupuk dasar yang dilakukan setiap dua minggu sekali; (8) Setelah kualitas air sesuai standar, kemudian benur ditebar. 


\section{Penebaran Benur}

Benur yang akan ditebar harus memenuhi persyaratan (1) Bebas dari virus TSV, WSSV, dan IHHNV; (2) Ukuran seragam; (3) Tubuh bening dan usus terlihat penuh; (4) Panjang lebih dari $8 \mathrm{~mm}$ (PL 10) dan insang telah sempurna; (5) Sebelum ditebar, benur diadaptasikan dahulu dengan suhu dan salinitas tambak yang akan ditebari.

Apabila benur yang ditebar didatangkan dari tempat yang jauh dari lokasi tambak dengan menggunakan sistem tertutup, maka kepadatan maksimun dalam kantong pada saat pengangkutan atau pengiriman adalah sebagai berikut: (1) Untuk ukuran lebih kecil dari PL 10 sebanyak 1.500--2.000 ekor/L dengan waktu angkut kurang dari 12 jam dan 1.000--1.500 ekor/L apabila lebih dari 12 jam; (2) Untuk ukuran lebih besar dari PL 10 sebanyak 1.000-1.500 ekor/L dengan waktu angkut kurang dari 12 jam dan 500--1.000 ekor/L bila lebih dari 12 jam (Anonim, 2003).

\section{Padat Tebar}

Teknik budidaya udang vanamei yang telah diaplikasikan di Indonesia termasuk di Sulawesi Selatan (Tabel 1).

Tabel 1. Sistem budidaya, padat penebaran, dan kisaran produksi udang vanamei di Indonesia

\begin{tabular}{lcc}
\hline Sistem budidaya & $\begin{array}{c}\text { Padat penebaran } \\
\text { (ekor/m } \mathbf{m}^{\mathbf{2}}\end{array}$ & $\begin{array}{c}\text { Kisaran produksi } \\
\text { (ton/ha) }\end{array}$ \\
\hline Tradisional & Kurang dari 15 & Lebih kecil dari 2,5 \\
Tradisional plus & $15--25$ & $2,5-4$ \\
Semi intensif & $26--40$ & $4--6,5$ \\
Intensif & $41-125$ & $6,5--20$ \\
Super intensif & $126--200$ & Lebih besar dari 20 \\
\hline
\end{tabular}

Sumber: Anonim (2003)

\section{Produksi yang telah dicapai pada setiap tingkat teknologi}

Teknik budidaya yang telah dijelaskan tersebut di atas adalah yang sudah baku berlaku umum di seluruh Indonesia, namun tingkat penerapannya tergantung kemampuan modal pembudidaya dari masing-masing daerah.

Di Sulawesi Selatan budidaya udang vanamei ini belum berkembang secara meluas di masyarakat dan baru terbatas di kalangan pengusaha tambak tertentu yang bermodal kuat, sehingga tingkat teknologi yang pernah diaplikasikan juga masih bervariasi tergantung kekuatan modal pembudidaya. Di Instalasi Tambak Percobaan Marana,
Balai Riset Perikanan Budidaya Air Payau, Maros, telah dilakukan serangkaian ujicoba budidaya udang vanamei dengan mengaplikasikan sistem budidaya tradisional dengan tingkat kepadatan $1--10 \mathrm{ekor} / \mathrm{m}^{2}$; produksi yang dicapai adalah 60--1.050 kg/ha/siklus. Sedangkan sistem budidaya tradisional plus yang telah dilakukan di Tambak Percobaan Punaga Takalar dengan menerapkan padat tebar 20 ekor/m² (200.000 ekor/ha) hasilnya dapat dicapai 11,6 ton/5,6 ha dengan produksi rata-rata sekitar 2,7 ton/ha/ siklus (Mansyur \& Mangampa, 2007). Sedangkan sistem budidaya semi dan intensif telah dilakukan oleh beberapa pengusaha tambak yang bermodal besar seperti PT Asindo di Kabupaten Takalar yang menerapkan padat tebar 125 ekor/m² dengan produksi yang dicapai sebesar 24 ton / ha/siklus. Pada umumnya informasi mengenai sistem budidaya dan produksinya yang berkembang pada pembudidaya tambak di Sulawesi Selatan sangat terbatas. Menurut Dinas Kelautan dan Perikanan Provinsi Sulawesi Selatan pada tahun 2005 di Kabupaten Bulukumba penerapan sistem budidaya udang vanamei secara intensif dapat mencapai 20,8 ton/ha/siklus dan di Kabupaten Takalar penerapan sistem budidaya tradisional plus mencapai produksi 3,5 ton/ha/siklus (Gambar 2).

Mengingat tambak di Sulawesi Selatan cukup luas yang siap pakai untuk kegiatan budidaya, termasuk untuk budidaya udang vanamei mencapai 90.540 ha (Tabel 2), maka peluang dan prospek pengembangan budidayanya juga cukup besar.

Seperempat dari luas tambak tersebut, diperkirakan merupakan bekas tambak udang windu intensif yang sampai saat ini masih kurang berproduksi dan hanya ditebari ikan bandeng dengan sistem budidaya tradisional. Di samping itu, tambak yang berstatus tambak tanah

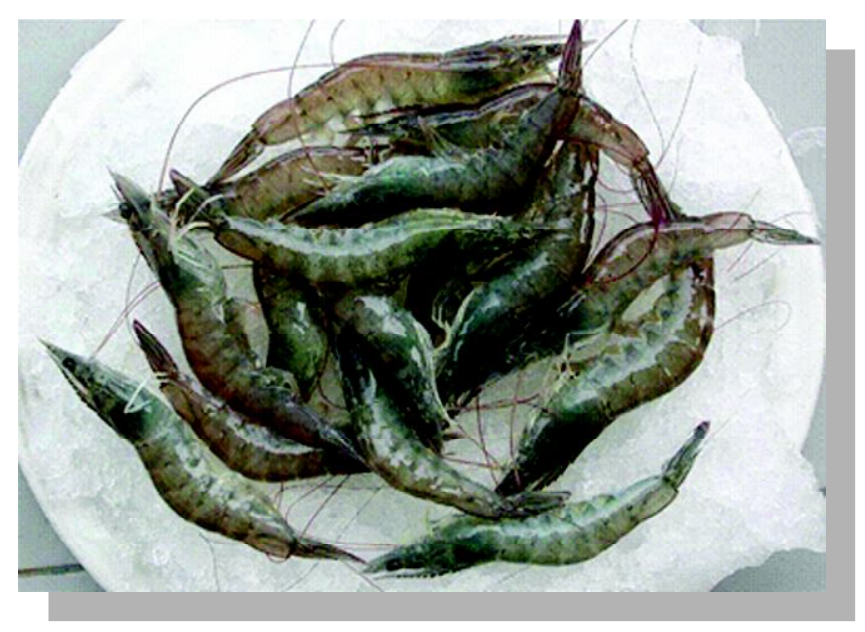

Gambar 2. Udang vanamei hasil panen dari tambak percobaan Punaga Takalar 
Tabel 2. Luas kotor dan bersih tambak di Sulawesi Selatan pada tahun 2005

\begin{tabular}{lcc}
\hline \multirow{2}{*}{ Kabupaten } & \multicolumn{2}{c}{ Luas tambak } \\
\cline { 2 - 3 } & Kotor & Bersih \\
\hline Luwu & 9,618 & 3,710 \\
Wajo & 10,869 & 12,924 \\
Bone & 7,773 & 9,945 \\
Sinjai & 455 & 662 \\
Bulukkumba & 3,666 & 3,576 \\
Selayar & 150 & 624 \\
Bantaeng & 106 & 170 \\
Jeneponto & 1,981 & 2,471 \\
Takalar & 2,800 & 4,000 \\
Makassar & 1,537 & 1,020 \\
Maros & 6,395 & 8,501 \\
Pangkep & 6,009 & 12,367 \\
Barru & 2,425 & 2,390 \\
Pare-Pare & 20 & 62 \\
Pinrang & 11,069 & 15,735 \\
Gowa & 76 & 128 \\
Luwu Utara & - & 6,147 \\
Luwu Timur & - & 5,223 \\
Palopo & - & 885 \\
\hline \multicolumn{1}{c}{ Jumlah } & $\mathbf{6 4 , 9 4 9}$ & $\mathbf{9 0 , 5 4 0}$ \\
\hline
\end{tabular}

Sumber: Anonim (2005)

sulfat masam masih cukup luas terutama di pesisir pantai timur Sulawesi Selatan. Jenis tambak tersebut kurang produktif dan digunakan untuk budidaya bandeng, bahkan banyak di antaranya yang ditelantarkan oleh pemiliknya karena kekurangan modal. Apabila potensi tambak tersebut dapat dikelola untuk pengembangan budidaya udang vanamei, maka produksi udang di Sulawesi Selatan dapat ditingkatkan berlipat ganda (Sugama, 2002).

Sebagai estimasi kasar kegiatan pertambakan di Sulawesi Selatan, dari $1 / 4 \times 90.540$ ha yaitu 22.635 ha yang selama ini tidak berproduksi, dikelola untuk budidaya udang vanamei dengan sistem budidaya tradisional plus saja (20 ekor/m²) dengan produksi 3,6 ton/ha/siklus seperti yang telah dicapai oleh Balai Riset Perikanan Budidaya Air Payau pada tahun 2007, maka kisaran produksi yang dapat dicapai adalah sekitar 22.635 ha $\times 3,6$ ton $=$ 81.486 ton/ha/siklus dengan nilai ekonomi sekitar 81.486.000 x Rp 25.000,- = Rp 2.037.150.000.000,- (Dua trilyun tiga puluh tujuh milyar seratus lima puluh juta rupiah).

\section{MASALAH DALAM PENGEMBANGAN}

Untuk pengembangan usaha budidaya udang vanamei di Sulawesi Selatan ada beberapa permasalahan baik yang bersifat non teknis maupun yang bersifat teknis antara lain adalah

\section{Masalah Modal dan Biaya Operasional}

Salah satu faktor yang menyebabkan pembudidaya tambak di Sulawesi Selatan susah menerima udang vanamei adalah mereka pada umumnya bermodal kecil dan berpandangan bahwa budidaya udang vanamei hanya cocok dan akan menguntungkan bila dibudidayakan secara semi intensif dan intensif, yang dalam operasionalnya memerlukan investasi cukup besar terutama biaya pakan dan harga bibit yang cukup mahal.

Keuntungan yang diperoleh dari budidaya udang vanamei juga akhirnya sangat kecil karena biaya operasionalnya yang tinggi tersebut. Di samping itu, udang vanamei juga sudah mulai dapat terkena penyakit virus white spot seperti yang terjadi pada udang windu.

Secara perhitungan rendahnya keuntungan yang diperoleh dari budidaya udang vanamei secara semi dan intensif disebabkan juga karena konversi pakan yang masih tinggi $(1,4-1,6)$ dan ukuran udang pada saat panen hanya 15--20 g/ekor, sedangkan harganya sekitar Rp 27.500,---Rp 29.500,-/kg, sedangkan biaya pakan untuk menghasilkan $1 \mathrm{~kg}$ udang tergantung dari tingkat teknologi yang diaplikasikan. Widodo \& Dian (2005) menyatakan bahwa biaya pakan untuk menghasilkan $1 \mathrm{~kg}$ udang sekitar Rp 16.000,--- Rp 17.000,-

Sebagai contoh hasil usaha pembudidaya udang vanamei apabila memiliki 1 ha tambak, dikelola secara tradisional plus dengan padat tebar $20 \mathrm{ekor} / \mathrm{m}^{2}$ (200.000 ekor/ha) dan mendapatkan produksi sebesar $3.600 \mathrm{~kg} / \mathrm{ha} /$ siklus (Tabel 3).

Contoh lain hasil usaha pembudidaya udang vanamei apabila memiliki 1 ha tambak yang dikelola secara tradisional dengan padat tebar 10 ekor/m² (100.000 ekor/ ha) dan mendapatkan produksi sebesar $1.260,8 \mathrm{~kg} / \mathrm{ha} /$ siklus (Tabel 4).

Berdasarkan estimasi dari kedua sistem budidaya tersebut, ternyata ada kecenderungan bahwa semakin tinggi padat tebar yang diaplikasikan, maka semakin tinggi pula keuntungan bersih yang diperoleh. Hal inilah yang melatarbelakangi banyak pengusaha tambak yang mengaplikasikan sistem budidaya intensif hingga super intensif (padat tebar 150--200 ekor $/ \mathrm{m}^{2}$ ). Mereka berpendapat bahwa semakin besar volume produksi semakin besar pula keuntungannya. Sistem budidaya seperti ini hanya mampu dilakukan oleh pembudidaya tambak yang bermodal besar atau kuat, sedangkan pada umumnya pembudidaya tambak di Sulawesi Selatan bermodal kecil atau lemah. 
Tabel 3. Hasil usaha pembudidaya udang vanamei secara tradisional plus

\begin{tabular}{lr}
\hline \multicolumn{1}{c}{ Jenis kegiatan } & $\begin{array}{c}\text { Besaran Harga } \\
\text { (Rp) }\end{array}$ \\
\hline Biaya pakan 3.600 kg x Rp 16.000,- & 57.760 .000 \\
Biaya benih, pupuk, obat-obatan, solar, dan lain-lain & 12.860 .000 \\
Biaya sewa tambak, pompa, dan penyusutan & 7.750 .000 \\
Biaya upah jaga sebesar 2\%dari keuntungan bersih & 5.566 .000 \\
Total biaya operasional & 83.936 .000 \\
Harga jual udang 3.600 kg x Rp 29.500,- & 106.200 .000 \\
Keuntungan bersih & 22.264 .000 \\
\hline
\end{tabular}

Tabel 4. Hasil usaha pembudidaya udang vanamei secara tradisional

\begin{tabular}{lr}
\hline \multicolumn{1}{c}{ Jenis kegiatan } & $\begin{array}{c}\text { Besaran harga } \\
\text { (Rp) }\end{array}$ \\
\hline Total biaya operasional & $29.590 .000,-$ \\
Harga jual udang $1.260,8 \mathrm{~kg} \times \mathrm{Rp} 29.500,-$ & $37.193 .000,-$ \\
Keuntungan bersih & $7.603 .000,--$ \\
\hline
\end{tabular}

\section{Masalah Penyakit}

Selain permasalahan biaya operasional yang cukup tinggi, masalah penyakit virus seperti WhiteSpot Syndrome Virus (WSSV) dan Taura Syndrome Virus (TSV) merupakan ancaman yang serius. Penyakit virus Taura merupakan salah satu jenis virus yang berbahaya karena dapat menyebabkan kematian total bagi udang putih termasuk udang vanamei yang dibudidayakan di tambak. Serangan virus TSV ini sebelum masuk ke Indonesia pernah menggemparkan pengusaha udang vanamei di Ekuador, Taiwan, dan Malaysia, kemudian menyebar ke Indonesia, yang pertama kali terjadi adalah di Banyuwangi, kemudian menyebar ke seluruh Jawa Timur, selanjutnya meluas ke seluruh Indonesia seperti Lampung dan daerah lainnya (Sugama, 2002).

Di Sulawesi Selatan penyakit yang diduga jenis penyakit TSV ini mulai muncul pada tahun 2005, dan sampai saat ini semakin merajalela seperti yang terjadi di Instalasi Tambak Percobaan Balai Riset Perikanan Budidaya Air Payau yang berlokasi di Marana pada tahun 2006 dan di Takalar pada tahun 2007. Pada tahun 2007 di Instalasi Tambak Percobaan Balai Riset Perikanan Budidaya Air Payau yang berlokasi di Takalar telah dilakukan budidaya udang vanamei pada 14 petak tambak, 6 petak di antaranya dipanen secara normal (tanpa serangan penyakit) dan 8 petak lainnya terserang penyakit tersebut sehingga dipanen sebelum waktunya. Produksi yang dicapai pada petakan tambak yang dipanen normal (tidak terserang penyakit) mencapai 3,6 ton/ha/siklus dengan padat tebar 20 ekor $/ \mathrm{m}^{2}$ selama pemeliharaan 105 hari. Sedangkan petakan tambak yang dipanen sebelum waktunya (terserang penyakit) produksinya sangat rendah hanya sekitar 1 ton/ha/siklus.

Salah satu faktor yang dapat menyebabkan timbulnya penyakit adalah jeleknya kondisi lingkungan dalam hal ini kualitas air tambak, di samping mutu benih yang ditebar. Jenis penyakit yang menyerang pertambakan budidaya udang vanamei di Sulawesi Selatan belum diketahui secara pasti, namun berdasarkan keterangan dari pembudidaya bahwa penyakit yang menyerang udang budidaya tersebut adalah jenis virus WSSV. Oleh karena udang yang terserang penyakit sebagian masih sempat dipanen. Sedangkan bila virus TSV yang menyerang udang umumnya terjadi kematian secara massal $(100 \%$ dalam waktu yang singkat (Sugama, 2002).

\section{Karakter dan Tradisi Masyarakat Pesisir Sulawesi Selatan}

Masyarakat pembudidaya tambak di Sulawesi Selatan pada umumnya memelihara udang windu dengan pola mulai dari sistem tradisional hingga intensif, di samping memelihara bandeng secara tradisional baik monokultur maupun polikultur dengan udang. Secara turun-temurun budidaya ikan bandeng ini walaupun harganya jauh lebih murah dibandingkan dengan harga udang, namun tetap dipertahankan, hal ini disebabkan karena tradisi budaya atau kebiasaan masyarakat Sulawesi Selatan utamanya yang berdomisili di daerah pesisir bahwa ikan bandeng merupakan lauk pauk utama bagi kehidupan masyarakat sehari-hari.

Di samping itu, ikan bandeng juga sangat laris dan laku pada hari-hari besar seperti Maulid, Israj Miraj, hari raya, dan acara hajatan karena tradisi di masyarakat yang selalu menggunakan bandeng sebagai lauk utama.

Setelah budidaya udang windu mengalami kegagalan akibat serangan penyakit WSSV, maka masyarakat pembudidaya kembali memelihara ikan bandeng, walaupun keuntungan yang diperoleh sangat kecil, karena harga ikan bandeng hanya sekitar Rp 10.000,-/kg. Bagi pembudidaya untuk beralih dari ikan bandeng ke udang vanamei mengalami kesulitan. Hal ini disebabkan oleh adanya pandangan atau persepsi yang keliru sebagian besar pembudidaya di Sulawesi Selatan beranggapan bahwa udang vanamei hanya cocok bila dibudidayakan secara semi intensif dan intensif yang hanya dapat dilakukan oleh pengusaha yang bermodal besar. 


\section{ALTERNATIF PEMECAHAN MASALAH}

Untuk memajukan pengembangan budidaya udang vanamei di Sulawesi Selatan, maka semua masalah tersebut perlu dilakukan pemecahannya meliputi hal-hal sebagai berikut: (1) mengadakan diseminasi atau penyuluhan terhadap pembudidaya, bahwa udang vanamei bukan hanya cocok untuk budidaya semi intensif dan intensif, tetapi dapat juga dilakukan dengan sistem budidaya tradisional dan tradisional plus dengan keuntungan yang cukup baik; (2) untuk menghindari serangan penyakit perlu dilakukan pengadaan breeding center udang vanamei; (3) diagnosa penyakit TSV, WSSV, dan IHHNV secara dini mulai dari calon induk yang hendak digunakan di panti benih atau hatcheri, benur hingga pada masa pemeliharaan di tambak; (4) sosialisasi tentang pemahaman dan penerapan pengelolaan kesehatan udang yang terintegrasi dan ramah lingkungan; (5) diseminasi teknologi budidaya udang vanamei bebas penyakit "melalui tambak percontohan Dempond"; (6) pembentukan koperasi usaha yang saling menguntungkan antar seluruh komponen yang terlibat dalam produksi udang nasional, dan; (7) memberi pengertian dan pembinaan kepada pembudidaya tambak di Sulawesi Selatan, bahwa di samping mempertahankan budidaya bandeng, juga perlu dikembangkan usaha budidaya udang vanamei, karena udang vanamei juga merupakan komoditas ekspor.

\section{PENUTUP}

Dengan potensi tambak yang luas di Sulawesi Selatan, peluang pengembangan budidaya udang vanamei sangat besar. Udang vanamei sebagai komoditas alternatif memiliki beberapa kelebihan atau keunggulan dibandingkan komoditas alternatif lainnya seperti udang windu dan masih memiliki peluang pasar ekspor serta total biaya produksi juga lebih kecil. Namun saat ini perlu disosialisasikan ke pembudidaya yang pada umumnya bermodal kecil dan dipertimbangkan dari segi ekonomisnya. Besar kecilnya keuntungan yang dihasilkan dari kegiatan budidaya tambak tergantung jenis teknologi yang diaplikasikan seperti sistem tradisional, semi intensif atau intensif. Pada umumnya yang menguntungkan hanya dikelola secara intensif yang disertai dengan pengelolaan mutu air yang baik dan efisiensi pakan selama operasional budidaya. Penurunan mutu air tambak pada budidaya udang vanamei juga dapat menyebabkan serangan penyakit virus white spot atau White Spot Syndrome Virus (WSSV) yang ditandai dengan pertumbuhan yang sangat lambat seperti halnya terjadi pada udang windu. Harga udang vanamei lebih murah dari pada udang windu sehingga perlu diperhitungkan dengan harga pakan yang diberikan. Untuk memajukan pengembangan budidaya udang vanamei di
Sulawesi Selatan perlu dilakukan pemecahan masalah meliputi hal-hal sebagai berikut: (1) mengadakan diseminasi atau penyuluhan terhadap pembudidaya, bahwa budidaya udang vanamei bisa dilakukan mulai dari sistem tradisional, tradisional plus, semi intensif hingga intensif dengan keuntungan yang cukup baik; (2) untuk menghindari serangan penyakit perlu dilakukan pengadaan breeding center udang vanamei; (3) diagnosa penyakit TSV, WSSV, dan IHHNV secara dini mulai dari calon induk yang hendak digunakan di panti benih atau hatcheri, benur hingga pada masa pemeliharaan di tambak; (4) sosialisasi tentang pemahaman dan penerapan pengelolaan kesehatan udang yang terintegrasi dan ramah lingkungan; (5) diseminasi teknologi budidaya udang vanamei bebas penyakit "melalui tambak percontohan Dempond"; (6) pembentukan koperasi usaha yang saling menguntungkan antar seluruh komponen yang terlibat dalam produksi udang nasional; dan (7) memberi pengertian dan pembinaan kepada pembudidaya tambak di Sulawesi Selatan, bahwa di samping mempertahankan budidaya bandeng, juga perlu dikembangkan usaha budidaya udang vanamei, karena udang vanamei juga merupakan komoditas ekspor.

\section{DAFTAR PUSTAKA}

Anonim. 2001. Laporan Statistik Perikanan Sulawesi Selatan. Dinas Perikanan dan Kelautan Provinsi Sulawesi Selatan, Makassar. 147 pp.

Anonim. 2003. Litopenaeus vannamei, sebagai alternatif budidaya udang saat ini. PT Central Proteinaprima (Charoen Pokphand Group). 12 pp.

Anonim. 2005. Laporan Statistik Perikanan Sulawesi Selatan. Dinas Perikanan dan Kelautan Provinsi Sulawesi Selatan, Makassar. 261 pp.

Benzie, J.A.H. 2000. Population genetic structure in penaeid prawans. Aquaculture Research. (31): 95- 119.

Briggs, M., S.F. Smith, R. Subanghe, and M. Philpps. 2004. Introduction and Movement of Penaeus vannamei and P. stylirostis in Asia and the Pacific. FAO Bangkok. 40 $\mathrm{pp}$.

Haliman, R.W. dan D.S. Adijaya. 2005. Udang Vanamei. Seri Agribisnis: Pembudidayaan dan prospek pasar udang putih yang tahan penyakit. Penebar Swadaya. Jakarta. 74 pp.

Garcia, S. and L. Le Reste. 1981. Life cycles dynamics, exploitation, and management of coastal penaeid shrimp stock. FAO Fish. Tech. Pap. (203): 20- 15.

Kurshy, N. and D.A. Davis. 2000. Protein requirement for maintenance and maximum weight gain for the pacific white shrimp, Litopenaeus vannamei. Fishery 
and Mariculture Laboratory. Marine Science Insitute. The University of Texas at Austin. 16 pp.

Lin, Y.C., Chen, J.C. 2001. Acute toxcity of amonia on Litopenaeus vannamei Boone juveniles at different salinity levels. J. Exp. Mar. Biol. Ecol. (259): 109- 119.

Mansyur, A. dan M. Mangampa. 2007. Membangkitkan kembali gairah petambak melalui budidaya udang vannamei (Litopenaeus vannamei) dengan kepadatan rendah. M edia Akuakultur. 2(2): 62-66.

Sprague, J.B. 1971. Measurement of pollutant toxicity to fish: III sublethal exfect and safe concentration Water Res. (4): 3- 18.

Sugama, K. 2002. Status budidaya udang introduksi Litopenaeus vannamei dan Litopenaeus Stylirostris serta prospek pengembangannya dalam tambak air tawar. Disampaikan dalam Temu Bisnis Udang. Makassar, 19 Oktober 2002. 7 pp.

Sihombing, B., E. Puspa, dan Sumbardo. 2005. Kliping Kumpulan Budidaya Udang. Buku II. Pusat Riset Perikanan Budidaya. Jakarta. 6 pp.

Travis, S.E. 2002. Hurricane Mitch: Shrimp population assessments in Gulf of Fonseca. Honduras: USGS Open Report 03-174. 30 pp.

Widodo, R.H. dan Dian A.S. 2005. Udang vannamei: pembudidayaan dan prospek pasar udang putih yang tahan penyakit. Penebar Swadaya. Jakarta. 75 pp. 